\title{
The Effect of The Height of a Second-Degree Relative on Children with Short Stature
}

\author{
${ }^{1}$ Health Sciences University, Istanbul Kanuni Sultan Suleyman \\ Training and Research Hospital, Department of Pediatrics, \\ Istanbul, Turkey \\ ${ }^{2}$ Health Sciences University, Istanbul Kanuni Sultan Suleyman \\ Training and Research Hospital, Department of Pediatric \\ Nutrition and Metabolism, Istanbul, Turkey
}

Seda Yılmaz Semerci ${ }^{1 \oplus}$, Hasan Önal ${ }^{2 \oplus}$, Neval Topal $^{1 \oplus}$, Rengin Şiraneci ${ }^{1 \oplus}$

\section{ABSTRACT}

Cite as: Yılmaz Semerci S, Önal H, Topal N, Şiraneci R. The effect of the height of a second-degree relative on children with short stature. Trends in Pediatrics 2021;2(2):60-6.

Received: 20 April 2021

Accepted: 01 June 2021

Publication date: 29 June 2021

Keywords: Second degree relative height, short stature, target height

Seda Yilmaz Semerci

Health Sciences University, Istanbul Kanuni Sultan Suleyman Training and Research Hospital, Department of Pediatrics, Istanbul, Turkey

ORCID: 0000-0002-0411-9610

sedayilmazsemerci@gmail.com
Objective: This study aimed to investigate the effect of the heights of second-degree relatives on adult height.

Methods: This was a cross-sectional study. Healthy children who applied to the general pediatric outpatient clinic to monitor the development of growth were considered as control group. Case group consisted of patients over 3 years of age with genetic, idiopathic short stature or without short stature but below the target height. All participants had either an uncle and an aunt with a short stature. Two groups were compared for their demographic characteristics and family information.

Results: The control group consisted of 43 children who were older than 3 years. A total of 101 cases of short stature were included in the study. Prevalence rates of idiopathic (39.6\%: $n=40)$, familial (36.6\%: $n=37)$, and constitutional (23.7\%: $n=24)$ short stature were as indicated. When the males included in the study were examined from different perspectives (case, control, presence of consanguineous marriage), the height of the uncle was predicted to be closer to or equal to the target height.

Conclusion: In case of short stature, the 'target height' criterion alone is shown to be not reliable in the assessment of genetic compatibility as well as the deviation from the predicted final height. Predicted final height was demonstrated to be similar to aunt height for girls and uncle height for boys. Therefore, the height of a second-degree relative can be used as an aid in the estimation.

\section{INTRODUCTION}

Short stature (SS) is defined as having the height below the 3rd percentile according to age and sex, or having two standard deviations lower than the average by age and sex. SS, affecting $2 \%-3 \%$ of the population, is a serious problem that is one of the main reasons for applications to pediatric endocrinology outpatient clinics. ${ }^{1}$ Since height is one of the most important indicators of growth in children, differential diagnosis of SS is possible by primarily evaluating growth. However, not all children below the 3rd percentile show a pathology for growth, most of them are healthy children called variants of normal. ${ }^{2}$ Approximately $2 / 3$ of the applications to the reference endocrine centers with the complaint of SS in the evaluation of growth consist of children with variants of normal. ${ }^{2}$ Familial (genetic) SS (FSS) is a definition used for children whose current height is below the 3rd percentile, but whose height is suitable for their target height (TH). ${ }^{3}$ Although the child with constitutional SS, has a normal height at birth and in the first year of life, her/his height measurements gradually fall below the 3 rd percentile. ${ }^{4}$ In the literature, there is no significant difference in the proportion of SS between 
boys and girls in terms of numerical distribution for age groups. In many studies conducted around the world and in our country, variant SS is the most common cause. 5,6 Since the most common cause is variant of normal, including FSS, the role of genetic factors has to be examined carefully. Human height is a complex feature under the control of both genetic and environmental factors. The inheritance rate of the height is above $50 \%$ and the inheritability of the height is the highest among complex human characteristics. ${ }^{6,7}$ In addition to genetic factors, many factors such as intrauterine conditions, the environment in which the child is raised, nutrition, endocrine factors, diseases, socioeconomic status and psychological state affect final height. ${ }^{3}$ Genetic effects in linear growth are associated with more than one gene. There is a $50 \%$ similarity between mother, father and siblings and the genes of the child, $25 \%$ with grandmother, grandfather, uncle-aunt and $12.5 \%$ with cousins. ${ }^{8}$ If the individuals with SS in the family are closer to the child in terms of consanguinity, then the child will more likely have an SS. ${ }^{2}$ Although the genetic effect of parental height on the child's height is known, and anthropometry of relatives are considered to be important for short stature cases; there is no study in the literature on the possible effect of the height of second-degree relative on final height. ${ }^{9}$ To the best of our knowledge this study firstly aimed to investigate the possible effect of seconddegree relatives on final height in the literature.

Methods This was a cross-sectional study completed within one year. Ethics committee approval was received from study hospital's local ethics committee for this study. Informed consent was obtained from parents and children. The case group consisted of the patients who were followed up in the outpatient clinic of Pediatric Endocrinology and NutritionMetabolism of our hospital. Children, who were followed up for routine care of healthy child at pediatric outpatient clinic of study center, consisted the control group. The case group consisted of patients with familial SS, idiopathic SS, without SS but remained below the target height (TH), and also had aunt(s) and uncle(s). SS was defined as having the height below the 3rd percentile according to age and sex, or having two standard deviations lower than the average by age and sex using reference values for Turkish children. ${ }^{10}$ Familial SS is used for children whose current height is below the 3rd percentile, but whose height is suitable for their $\mathrm{TH}^{3}{ }^{3}$ The term idiopathic short stature (ISS) is used for those whose height is above 2 standard deviations but below the median height for gender and age without systemic, endocrine and/or chromosomal abnormalities. ${ }^{11}$ Pathologic short stature, being under the age of three years old, inadequate information, history of growth supplementation and lack of consent were reasons for exclusion. The children who did not have either a paternal aunt and a maternal uncle were also excluded. The heights of maternal uncle and paternal aunt of all participants were presented. In case of multiple aunts and/or uncles, the one who had the lowest height was included. Demographic characteristics of all patients were obtained. Age, sex, weight $(\mathrm{kg})$, height $(\mathrm{cm})$, target height $(\mathrm{cm})$, predicted final height (PAH), bone age, puberty staging, maternal height $(\mathrm{MH})$, paternal height $(\mathrm{PaH})$, heights of the aunt $(\mathrm{AH})$, and the uncle $(\mathrm{UH})$, age of the mother were recorded. The presence of parental consanguinity was noted. The heights of the individuals were measured while standing on barefoof, by the same trained person using a Harpenden Stadiometer sensitive to $0,1 \mathrm{~cm}$.

Weight measurements were performed by the same trained person using a portable scale sensitive to $0.1 \mathrm{~kg}$.

Bone age was determined by the same physician with the help of the hand - wrist atlas developed by Greulich - Pyle on the left-hand wrist radiograph. The Bayley - Pinneau method was used to calculate the $\mathrm{PAH}$. According to Tanner's TH formula, TH is calculated as (mother's height + father's height) $/ 2 \pm 6.5 \mathrm{~cm}$.

\section{Statistical Analysis}

Mean, standard deviation (SD), ratio and frequency values were used in descriptive statistics of the data. A sample size of 144 infants, at least 43 in each arm, is found to be sufficient to detect a clinically important difference between groups with $80 \%$ statistical power and a $5 \%$ level of significance. The data distribution was analyzed by Kolmogorov -Smirnov test. Independent sample t- test and Mann-Whitney $\mathrm{U}$ test were used for the analysis of the quantitative data. Chi-square test was used in the analysis of qualitative data. All data were shown as mean \pm SD. 
$p<0.05$ was considered significant. Statistical analysis was performed using SPSS 20.0 for Windows.

\section{RESULTS}

The study included 101 cases and 43 healthy children who were followed up in the outpatient clinic of Pediatric Endocrinology and Nutrition - Metabolism at study hospital. Demographic features of the study population are demonstrated in Table 1. There was no statistically significant difference between case and control groups as for distribution of genders, age, patients' height, and weight, bone age, $\mathrm{AH}, \mathrm{UH}$, puberty ratio and patient characteristics (Table 1). $\mathrm{PAH}$ in the case group was significantly lower in the control group (Table 1). In the case group, $\mathrm{TH}, \mathrm{MH}$, $\mathrm{PaH}$ and maternal menstruation age were significantly higher than the control group (all $p<0.05$ ) (Table 1). $\mathrm{TH}$ was significantly higher than the $\mathrm{PAH}$ in the case group (Table 2). Girls' $\mathrm{TH}$ and $\mathrm{AH}$ values were similar and both characteristics were significantly higher than the PAH in the case group (Table 2). No significant difference was found between girls' $\mathrm{PAH}$ vs $\mathrm{TH}$ and $\mathrm{PAH}$ vs $\mathrm{AH}$ (Table 2). $\mathrm{TH}$ and $\mathrm{UH}$ of boys were similar and both characteristics were not significantly different from the $\mathrm{PAH}$ in the case group (Table 2). In the control group, $\mathrm{TH}$ and $\mathrm{AH}$ of girls were similar and both of these parameters had no significant difference from the PAH (Table 2). In the control group, TH and UH of boys were significantly shorter than PAH (Table 2). The difference between $\mathrm{PAH}$ - TH was significantly higher than the difference between $\mathrm{PAH}$, and $\mathrm{UH}$ in the boys of the case group (Table 2). In the case group, $\mathrm{TH}$ and $\mathrm{AH}$ values were significantly higher than PAH of girls who did not have a history of parental consanguinity (Table 3 ). $\mathrm{UH}$ and $\mathrm{TH}$ were similar in boys without a history of parental consanguinity and those measures did not differ significantly from $\mathrm{PAH}$ in the case group (Table $3)$. In the control group, $\mathrm{TH}$ and $\mathrm{AH}$ values were not different than $\mathrm{PAH}$ of girls without a history of consanguineous marriages (Table 3 ). In the control group, TH and UH were significantly lower than PAH of boys without a history of parental consanguinity (Table 3). Besides, the difference between PAH, and $\mathrm{TH}$ was significantly higher than the difference between $\mathrm{PAH}$, and $\mathrm{UH}$ in boys without a history of parental consanguinity (Table 3 ). In the case group with a history of parental consanguinity. $\mathrm{TH}$ and $\mathrm{AH}$ of girls were significantly higher than their PAHs

Table 1. Comparison of demographic data between groups

\begin{tabular}{|c|c|c|c|}
\hline & $\begin{array}{c}\text { Case Group }(n=101) \\
n(\%) \\
\text { Mean } \pm \text { SD/SDS }\end{array}$ & $\begin{array}{c}\text { Control Group }(n=43) \\
n(\%) \\
\text { Mean } \pm \text { SD/SDS }\end{array}$ & $\mathbf{p}$ \\
\hline $\begin{array}{l}\text { Gender } \\
\text { Female } \\
\text { Male }\end{array}$ & $\begin{array}{l}48(47.5) \\
53(52.5)\end{array}$ & $\begin{array}{l}19(44.2) \\
24(55.8)\end{array}$ & 0.713 \\
\hline $\begin{array}{l}\text { Age } \\
\text { Predicted Height }(\mathrm{cm}) \\
\text { Target Height-SDS }(\mathrm{cm})\end{array}$ & $\begin{array}{c}10.06 \pm 3.77 \\
159.79 \pm 12.70 \\
2.80 \pm 0.8 \\
163.51 \pm 9.35\end{array}$ & $\begin{array}{c}9.60 \pm 3.45 \\
166.72 \pm 11.70 \\
2.92 \pm 0.43 \\
160.09 \pm 7.86\end{array}$ & $\begin{array}{l}0.498 \\
0.007 \\
0.749 \\
0.117\end{array}$ \\
\hline Height-SDS (cm) & $\begin{array}{c}-2.83 \pm 1.07 \\
(124.88 \pm 19.13)\end{array}$ & $\begin{array}{c}2.54 \pm 0.35 \\
(131.40 \pm 21.60)\end{array}$ & $\begin{array}{c}<0.001 \\
0.074\end{array}$ \\
\hline BMI-SDS & $\begin{array}{c}0.76 \pm 0.44 \\
(14.83 \pm 2.59)\end{array}$ & $\begin{array}{c}0.63 \pm 0.34 \\
(14.31 \pm 2.22)\end{array}$ & $\begin{array}{l}0.669 \\
0.072\end{array}$ \\
\hline $\begin{array}{l}\text { Bone Age } \\
\text { Maternal Height } \\
\text { Paternal Height } \\
\text { Aunt Height } \\
\text { Uncle Height } \\
\text { Puberty }\end{array}$ & $\begin{array}{l}8.71 \pm 3.91 \\
156.7 \pm 6.7 \\
169.9 \pm 7.1 \\
157.8 \pm 8.3 \\
170.2 \pm 6.5\end{array}$ & $\begin{array}{l}9.21 \pm 3.88 \\
153.6 \pm 5.3 \\
165.2 \pm 8.5 \\
156.1 \pm 6.9 \\
170.7 \pm 6.4\end{array}$ & $\begin{array}{l}0.486 \\
0.007 \\
0.001 \\
0.263 \\
0.650\end{array}$ \\
\hline $\begin{array}{l}\text { No } \\
\text { Yes }\end{array}$ & $\begin{array}{l}58.0(57.4) \\
43.0(42.6)\end{array}$ & & 0.858 \\
\hline
\end{tabular}




\begin{tabular}{|c|c|c|c|c|c|}
\hline & & \multicolumn{4}{|c|}{ Difference from Predicted Height } \\
\hline & & Mean \pm SD & $\mathbf{p}$ & Mean $\pm S D$ & p \\
\hline \multirow{2}{*}{ Case Group } & $\begin{array}{l}\text { Female } \\
\text { Predicted Height } \\
\text { Target Height } \\
\text { Aunt Height }\end{array}$ & $\begin{array}{c}150.1 \pm 7.3 \\
156 \pm 5.5 \\
156 \pm 7.4\end{array}$ & $\begin{array}{c}<0.001 \\
0.001\end{array}$ & $\begin{array}{l}5.9 \pm 8 \\
6 \pm 9.9\end{array}$ & 0.995 \\
\hline & $\begin{array}{l}\text { Male } \\
\text { Predicted Height } \\
\text { Target Height } \\
\text { Aunt Height }\end{array}$ & $\begin{array}{l}169.4 \pm 9.1 \\
169.7 \pm 5.6 \\
170.9 \pm 6.2\end{array}$ & $\begin{array}{l}0.821 \\
0.312\end{array}$ & $\begin{array}{l}0.3 \pm 7.8 \\
1.7 \pm 9.1\end{array}$ & 0.117 \\
\hline \multirow{2}{*}{ Control Group } & $\begin{array}{l}\text { Female } \\
\text { Predicted Height } \\
\text { Target Height } \\
\text { Aunt Height }\end{array}$ & $\begin{array}{c}157.2 \pm 7 \\
154.7 \pm 5.5 \\
154.5 \pm 6\end{array}$ & $\begin{array}{c}0.056 \\
0.15\end{array}$ & $\begin{array}{c}2.5 \pm 5 \\
2.7 \pm 7.4\end{array}$ & 0.879 \\
\hline & $\begin{array}{l}\text { Male } \\
\text { Predicted Height } \\
\text { Target Height } \\
\text { Aunt Height }\end{array}$ & $\begin{array}{l}175.2 \pm 7.8 \\
165.4 \pm 5.9 \\
171.1 \pm 4.4\end{array}$ & $\begin{array}{c}<0.001 \\
0.043\end{array}$ & $\begin{array}{l}9.8 \pm 6.9 \\
4.2 \pm 8.2\end{array}$ & 0.001 \\
\hline
\end{tabular}

Table 3. Comparison of predicted height, target height and second degree relatives' heights between groups without consanguineous marriage

\begin{tabular}{|c|c|c|c|c|c|}
\hline & & \multicolumn{4}{|c|}{ Difference from Predicted Height } \\
\hline & & Mean \pm SD & $p$ & Mean \pm SD & $p$ \\
\hline \multirow{2}{*}{ Case Group } & $\begin{array}{l}\text { Female } \\
\text { Predicted Height }(\mathrm{cm}) \\
\text { Target Height } \\
\text { Aunt Height }\end{array}$ & $\begin{array}{c}149.9 \pm 6.0 \\
155 \pm 5 \\
155.7 \pm 7\end{array}$ & $\begin{array}{l}0.002 \\
0.011\end{array}$ & $\begin{array}{c}5.1 \pm 8.1 \\
5.8 \pm 11.1\end{array}$ & 0.643 \\
\hline & $\begin{array}{l}\text { Male } \\
\text { Predicted Height } \\
\text { Target Height } \\
\text { Aunt Height }\end{array}$ & $\begin{array}{c}169.2 \pm 9.4 \\
169.9 \pm 6 \\
171.2 \pm 6.8\end{array}$ & $\begin{array}{l}0.642 \\
0.297\end{array}$ & $\begin{array}{c}0.6 \pm 7.5 \\
2 \pm 9.7\end{array}$ & 0.203 \\
\hline \multirow{2}{*}{ Control Group } & $\begin{array}{l}\text { Female } \\
\text { Predicted Height } \\
\text { Target Height } \\
\text { Aunt Height }\end{array}$ & $\begin{array}{c}158.2 \pm 7.2 \\
155.4 \pm 5.8 \\
155 \pm 5.9\end{array}$ & $\begin{array}{l}0.067 \\
0.113\end{array}$ & $\begin{array}{l}2.7 \pm 5.2 \\
3.2 \pm 7.1\end{array}$ & 0.778 \\
\hline & $\begin{array}{l}\text { Male } \\
\text { Predicted Height } \\
\text { Target Height } \\
\text { Aunt Height }\end{array}$ & $\begin{array}{c}176.7 \pm 6.5 \\
166.5 \pm 6.1 \\
171.8 \pm 4\end{array}$ & $\begin{array}{c}<0.001 \\
0.002\end{array}$ & $\begin{array}{c}10.2 \pm 6.1 \\
5 \pm 4.9\end{array}$ & 0.003 \\
\hline
\end{tabular}

(Table 4). Also, the difference between $\mathrm{PAH}$, and $\mathrm{AH}$ was lower than the difference between $\mathrm{PAH}$, and $\mathrm{TH}$ of girls (Table 4). TH and UH of boys did not differ significantly from $\mathrm{PAH}$ in the case group with a history of parental consanguinity (Table 4). In the control group with a history of parental consanguinity, $\mathrm{TH}$ and $\mathrm{AH}$ of girls were not significantly different from PAH (Table 4). TH and UH of boys did not differ significantly from PAH in the control group with a history of parental consanguinity (Table 4). 


\begin{tabular}{|c|c|c|c|c|c|}
\hline & & \multicolumn{4}{|c|}{ Difference from Predicted Height } \\
\hline & & Mean $\pm S D$ & $\mathbf{p}$ & Mean $\pm S D$ & p \\
\hline \multirow{2}{*}{ Case Group } & $\begin{array}{l}\text { Female } \\
\text { Predicted Height }(\mathrm{cm}) \\
\text { Target Height } \\
\text { Aunt Height }\end{array}$ & $\begin{array}{c}150.7 \pm 10.5 \\
158.8 \pm 6.4 \\
157 \pm 8.7\end{array}$ & $\begin{array}{l}0.008 \\
0.008\end{array}$ & $\begin{array}{l}8.2 \pm 7.5 \\
6.4 \pm 5.9\end{array}$ & 0.527 \\
\hline & $\begin{array}{l}\text { Male } \\
\text { Predicted Height } \\
\text { Target Height } \\
\text { Aunt Height }\end{array}$ & $\begin{array}{l}170.1 \pm 8.5 \\
169.3 \pm 4.5 \\
170.3 \pm 4.5\end{array}$ & $\begin{array}{l}0.773 \\
0.927\end{array}$ & $\begin{array}{c}0.6 \pm 9 \\
0.7 \pm 7.1\end{array}$ & 0.327 \\
\hline \multirow{2}{*}{ Control Group } & $\begin{array}{l}\text { Female } \\
\text { Predicted Height } \\
\text { Target Height } \\
\text { Aunt Height }\end{array}$ & $\begin{array}{l}152.7 \pm 4.7 \\
151.3 \pm 0.6 \\
152.3 \pm 7.5\end{array}$ & $\begin{array}{l}0.686 \\
0.959\end{array}$ & $\begin{array}{c}1.3 \pm 5 \\
0.3 \pm 9.9\end{array}$ & 0.826 \\
\hline & $\begin{array}{l}\text { Male } \\
\text { Predicted Height } \\
\text { Target Height } \\
\text { Aunt Height }\end{array}$ & $\begin{array}{c}171 \pm 10.3 \\
162.4 \pm 4.8 \\
169.2 \pm 5.5\end{array}$ & $\begin{array}{l}0.124 \\
0.797\end{array}$ & $\begin{array}{c}8.7 \pm 9.7 \\
1.9 \pm 14.6\end{array}$ & 0.123 \\
\hline
\end{tabular}

\section{DISCUSSION}

Although SS is a health problem affecting $2 \%-3 \%$ of the population, there is no significant difference in the prevalence rate of SS between boys and girls in terms of numerical distribution for age groups. ${ }^{9}$ The idea that there may be more criteria than $\mathrm{TH}$ calculation is required in the assessment of height and PAH estimation formed the starting point of our study. In a study conducted in 2009, the control of compliance of human height with the genetic potential introduced a stimulating criterion, especially in cases with slight deviation of stature in growth chart, and predicted that the reliability of $\mathrm{TH}$ was not the same in all cases. ${ }^{12}$ In this study, it has been proven that as the degree of deviation in height increases, the incompatibility of height to genetic potential becomes evident. Therefore, the confidence interval of $\mathrm{TH}$ decreases, especially in case of SS and this finding necessitates new evaluation methods other than using this criterion. ${ }^{12}$ Distributions of SS in pediatric endocrine outpatient clinics do not match the rates given for the normal population. In the interpretation of short stature in children, adaptation to the genetic potential should not be neglected in addition to height deviation. Not all idiopathic short stature cases show normal variant characteristics. This perspective is important for further investigation and treatment approaches. The most frequent type of SS is determined as constitutional SS in boys and familial SS in girls. ${ }^{13}$ Overall, Lindsay et al. ${ }^{14}$ reported pathological causes accounted for $18.9 \%$ and Bhadada et al. ${ }^{7}$ 63.9\%, Zafer et al. ${ }^{15} 34.3 \%$; Topal et al. ${ }^{16} 47.1 \%$ of cases with SS. Variability in these findings may be due to differences in socioeconomic conditions. As the socioeconomic level increases, the frequency of admission to patients with variant SS increases and pathological causes can be caught earlier and treated without the development of severe SS. ${ }^{17}$ In many studies conducted around the world and in our country, variants of normal is the most common cause. ${ }^{6,15}$ In this study, the most common reason for SS was the variance of normal SS with a rate of $60.3 \%$. In the variant of normal, SS does not show a significant difference from the final height. Since the variant of the normal was the cause of the majority of the individuals included in our study, this was a factor that decreases the statistical significance of the results. For stronger statistical results, new studies may be required in which long-term evaluation of cases is performed. While it is stated that familial SS is in the foreground in girls, constitutional SS is the mostly seen one in boys. ${ }^{15}$ 
In the present study, familial SS in boys was the leading cause with a rate of $40.4 \%(n=21)$. It was seen that idiopathic SS was the most common cause in girls with a rate of $46.9 \%(n=23)$. This may be due to the fact that the SS distribution in patients referred to the pediatric endocrine outpatient clinic, varies with the normal population. According to the subject of the study, it is expected that the presence of consanguineous marriage will significantly increase the similarity between the heights of second-degree relatives. The rate of consanguineous marriages in our study was $25 \%$ (27\% in the case group, and $20 \%$ in the control group) and was similar to the $20 \%$ (17\% in Istanbul and Izmir - 36\% in the villages) reported in the literature for Turkey. ${ }^{18}$ When the groups with and without consanguineous marriages were compared without gender discrimination, no significant difference was found (data not shown). However, when only male gender was considered, it was concluded that $\mathrm{UH}$ was closer to $\mathrm{PAH}$ than $\mathrm{TH}$ in both case and control groups. In girls, there was no significant difference between the groups with and without a history of consanguineous marriages. This can be explained by the fact that the maternal height is very similar with $\mathrm{UH}$ in families with consanguineous marriages and that the height of girls is less inheritable than boys. When only the case group is considered, although $\mathrm{AH}$ has no superiority to $\mathrm{TH}, \mathrm{AH}$ can be used instead of $\mathrm{TH}$ for girls. In this study, the most common cause of idiopathic factors in girls may have contributed to this result. In a study conducted in 2011, SS was found in index cases and aunts. ${ }^{19}$ New studies are needed to explain the fact that the index cases do not have the same proportion of aunt similarity in their sisters in this study. When case group boys were examined, it was seen that UH was closer to $\mathrm{PAH}$ rather than $\mathrm{TH}$. In the control group boys, $\mathrm{UH}$ was found to be significantly superior to $\mathrm{TH}$ in estimating $\mathrm{PAH}$. When the groups compared in terms of the effect of consanguineous marriages on SS, similarity of PAH to UH was found to be higher in the case group with a history of consanguineous marriage. Supporting our/investigators' hypothesis, when control groups with and without a history of consanguineous marriages were compared, similarity of PAH to UH was found to be significantly higher in a group with a history of consanguineous marriage.

\section{Limitations}

This study has limitations such as restricted number of participants and relatively short follow-up time of participants. A more powerful study with a prospective trial design has to include a larger number of participants. Also for this subject, final height must be investigated so as to achieve statistically more powerful results.

\section{CONCLUSION}

In the case of SS, the 'target height' criterion alone is shown to be not reliable in the assessment of genetic compatibility as well as the deviation from $\mathrm{PAH}$. $\mathrm{PAH}$ was demonstrated to be statistically similar with $\mathrm{AH}$ for girls and with UH for boys. In the presence of consanguineous marriage, the correlation was found to be more pronounced in boys. With these data, it is thought that heights of second- degree relatives can be used as an additional criterion in the estimation of final height, especially in case of nonpathological short stature.

Ethics Committee Approval: The study was approved by local Ethics Committee of study hospital (Ethics Committee approval number: 260/2009.06.25).

Conflict of Interest: The authors declared no potential conflicts of interest with respect to the research, authorship, and/or publication of this article.

Funding: The authors received no financial support for the research, authorship, and/or publication of this article.

Informed Consent: Parents of the patient provided informed consent to publish the report.

\section{REFERENCES}

1. Current Diagnosis and Treatment Pediatrics. Hay WW, Levin MJ, Sondheimer JM, Deterding Robin R. Ankara, Güneş Medical Publishing, 2013;945-51.

2. Pediatric Endocrinology. Gün ZH, Cal G, Yordam N, Kurtoğlu S. Society of Pediatric Endocrinology and Auxology Publications, 2003;65-78.

3. Pediatrics, Neyzi O, Ertuğrul T et al. Istanbul, Nobel Medical Publishing, 2010;137-49.

4. Child Health and Diseases. Cantez T, Baysal SU, Oğuz F, Omeroğlu Eker R. Nobel Medical Publishing, 2003;8389.

5. Kayıran Gen P, Taymaz T, Kayıran SM, et al. The frequency of overweight, obesity and short stature among primary school students in three different 
regions of Turkey. The Medical Bulletin of Sisli Etfal Hospital. 2011;45:13-8.

6. Saengkaew T, McNeil E, Jaruratanasirikul S. Etiologies of short stature in a pediatric endocrine clinic in Southern Thailand. J Pediatr Endocrinol Metab. 2017;30:1265-70.

https://doi.org/10.1515/jpem-2017-0205

7. Bhadada SK, Agrawal NK, Sing SK, Agrawal JK. Etiological profile of short stature. Indian J Pediatr. 2003;70:545-7.

https://doi.org/10.1007/BF02723154

8. Anggreainy MS, Widyanto MR, Widjaja B, Soedarsono $\mathrm{N}$, Widodo PT. Family relation and STR-DNA matching using fuzzy inference. International Journal of Electrical \& Computer Engineering. 2019;9:1335-45. https://doi.org/10.11591/ijece.v9i2.pp1335-1345

9. Collett-Solberg PF, Ambler G, Backeljauw PF, et al. Diagnosis, Genetics, and Therapy of Short Stature in Children: A Growth Hormone Research Society International Perspective. Horm Res Paediatr. 2019;92:1-14. https://doi.org/10.1159/000502231

10. Neyzi O, Bundak R, Gökçay G, et al. Reference Values for Weight, Height, Head Circumference, and Body Mass Index in Turkish Children. J Clin Res Pediatr Endocrinol. 2015;7:280-93. https://doi.org/10.4274/jcrpe.2183

11. Wit JM, Ranke MB, Kelnar CJH. ESPE classification of paediatric endocrine diagnoses. Horm Res. 2007;68:1120.

https://doi.org/10.1159/isbn.978-3-318-01488-4

12. Alaçakır N, Öçal G, Berberoğlu M, şıklar Z, Bilir P.
Anthropometric and diagnostical characteristics of short stature cases without chronic systemic disease admitted to endocrinology policlinic. Turkish Journal of Pediatric Disease. 2009;3:23-33.

13. Locey KA, Parkin JM. Causes of Short Stature, A community study of children in New Castle - upon Tyne. Lancet. 1974;1:42-5. https://doi.org/10.1016/S0140-6736(74)93041-4

14. Lindsay R, Feldkamp M, Haris D, Robertson J, Rallison M. Utah Growth Study: Growth standarts and the prevalence of growth hormone deficiency. J Pediatr. 1994;125:29-35. https://doi.org/10.1016/S0022-3476(94)70117-2

15. Zafer Y, Kandemir N, Yordam N. Etiological distribution of short stature: investigation of 1013 cases. Journal of Child Health and Diseases. 1999;42:205-13.

16. Topal Y, Teziç T, Topal H, Karacan C. Evaluation of the short stature cases in a reference center. New Medical Journal. 2002;19:138-41.

17. Demirel F, Bideci A, Çamurdan MO, Arga M, Cinaz P. Etiological factors of short stature in children. Turk Arch Pediatr. 2005;40:39-43.

18. Beşpınar F, Beşpınar L. Double Picture of Structure of Household and Marriage in Turkey: The Reflection of Household Structures in addition to the Tradition. Journal of Population Science. 2017;39:109-49.

19. Mohn A, Marcovecchio ML, de Giorgis T, et al. An insulin-like growth factor-I receptor defect associated with short stature and impaired carbohydrate homeostasis in an Italian pedigree. Horm Res Paediatr. 2011;76:136-43.

https://doi.org/10.1159/000324957 